\title{
Insulin sensitivity and secretion and adipokine profile in patients with Cushing's disease treated with pasireotide
}

\author{
V. Guarnotta ${ }^{1}$ - G. Pizzolanti ${ }^{1}$ A. Ciresi ${ }^{1} \cdot$ C. Giordano ${ }^{1}$
}

Received: 19 November 2017 / Accepted: 22 January 2018

(C) Italian Society of Endocrinology (SIE) 2018

\begin{abstract}
Purpose To evaluate the effect of pasireotide on $\beta$-cell and adipose function in patients with Cushing's disease (CD). Methods Clinical and hormonal parameters, insulin secretion evaluated by HOMA- $\beta$ and by the area under the curve (AUC ${ }_{2 \mathrm{~h}}$ ) of C-peptide during a mixed meal tolerance test and insulin sensitivity, evaluated by the euglycaemic hyperinsulinaemic clamp, were evaluated in 12 patients with active $\mathrm{CD}$, before and after 6 and 12 months of pasireotide. In addition, a panel of adipokines including leptin $(\mathrm{Ob})$, leptin/leptin receptor ratio (Ob/Ob-R ratio), adiponectin, resistin, visfatin, adipocyte fatty acid binding protein (AFABP) and non-esterified fatty acids (NEFAs) was evaluated at baseline and after 12 months of pasireotide.

Results During 12 months of pasireotide treatment, a significant decrease in weight $(p=0.004)$, BMI $(p=0.008)$, waist circumference $(p=0.009)$, urinary free cortisol $(p=0.007)$, fasting insulinaemia $(p=0.007)$, HOMA- $\beta(p=0.015)$ and AUC 2h c-peptide $(p=0.017)$, concomitance with an increase in fasting glycaemia $(p=0.015)$ and HbA1c $(p=0.030)$, was found. With regard to adipokines, a significant decrease in $\mathrm{Ob}(p=0.039)$, Ob/Ob-R ratio $(p=0.017)$ and AFABP $(p=0.036)$ was observed concomitant with a significant increase in $\mathrm{Ob}-\mathrm{R}(p=0.028)$ after 12 months of pasireotide.

Conclusions 12 months of treatment with pasireotide in $\mathrm{CD}$ is associated with an impairment of insulin secretion and an improvement of adipose function without any interference in insulin sensitivity.
\end{abstract}

Keywords Pasireotide $\cdot$ Diabetes mellitus $\cdot$ Adipokines $\cdot$ Insulin sensitivity $\cdot$ Cushing's disease

\section{Introduction}

Cushing's disease $(\mathrm{CD})$ is a medical condition due to a pituitary ACTH-secreting tumour, associated with increased mortality [1]. Therefore, immediate treatment is required for these patients. Trans-sphenoidal surgery is generally the first-line treatment, but it is not always curative and sometimes contraindicated [2]. Additional treatment options include pituitary radiotherapy, bilateral adrenalectomy and/ or medical therapy [3-6].

V. Guarnotta and G. Pizzolanti contributed equally to this work.

C. Giordano

carla.giordano@unipa.it

1 Biomedical Department of Internal and Specialist Medicine (DIBIMIS), Section of Diabetes, Endocrinology and Metabolism, University of Palermo, Piazza delle Cliniche 2, 90127 Palermo, Italy
The multireceptor-targeted somatostatin analogue (SSA) pasireotide has shown favourable results in the treatment of adult patients with $\mathrm{CD}$ who are not candidates for surgery or when surgery has failed [7-9]. In the phase-II, proof-of-concept, open-label, single-arm, 15-day multicentre study conducted on 39 patients with $\mathrm{CD}$, pasireotide $600 \mu \mathrm{g}$ administered twice daily induced full disease control, defined as urinary free cortisol levels (UFC) within or below the normal range in $17 \%$ of patients. In addition, pasireotide treatment was also associated with significant improvements in systolic and diastolic blood pressure, total cholesterol, LDL cholesterol, weight, BMI, waist circumference and quality of life [10-12].

The most common adverse events associated with pasireotide, such as gastrointestinal disorders and cholelithiasis, were similar to those observed with other SSAs. However, $36 \%$ of patients developed hyperglycaemia as an adverse event and 1 out of 29 discontinued the treatment because of grade 2 hyperglycaemia [7]. In the pivotal phase-III study conducted in 162 patients with $\mathrm{CD}$, hyperglycaemia 
was observed in $73 \%$ of patients and in $6 \%$ led to discontinuation of the treatment. In the whole study population (including diabetic patients), $\mathrm{HbA} 1 \mathrm{c}$ increased up to $2 \%$ after 12 months. Interestingly, hyperglycaemia was more common in patients with pre-existing impairment of glucose metabolism [8].

A few studies have been performed to evaluate the specific impact of pasireotide on glucose metabolism in healthy volunteers [13] while, currently, the available data on patients with $\mathrm{CD}$ are scarce.

$\mathrm{CD}$ is well known to be associated with obesity, insulin resistance and various degrees of carbohydrate intolerance, even though the pathogenesis of these disturbances seems not to be directly associated with hypercortisolism $[14,15]$. On the other hand, visceral adiposity has been shown to be a main determinant of insulin resistance and of cardiovascular risk in the general population [16-18]. The emerging paradigm of adipose tissue dysfunction supports the view that adipose tissue dysregulation (altered fat distribution and function) might play a crucial role in the pathogenesis of insulin resistance and atherosclerosis. From this viewpoint, atherosclerotic cardiovascular disease and diabetes seem to arise from a "common soil", characterized by altered adipokine production, increase in the lipolytic activity of adipose tissue and low-grade inflammation [19-21]. Although pasireotide treatment has been associated with a significant impact on both visceral obesity and glucose levels [8], currently sufficient data on adipokine levels in this setting are not available.

The aim of this study was to fully evaluate the effects of 12 months of pasireotide treatment on glucose metabolism and adipose function in a cohort of patients with $\mathrm{CD}$.

\section{Materials and methods}

\section{Subjects and study design}

Of a total of 15 patients with active $\mathrm{CD}$ after pituitary surgery, referred to the Division of Endocrinology of Palermo University from May 2013 to December 2016, 10 women (83\%) and 2 men (17\%) [median age 39.5 (21-53) years; median BMI $\left.36.1(26.8-55) \mathrm{kg} / \mathrm{m}^{2}\right]$ were prospectively included in the study. The diagnosis of $\mathrm{CD}$ was based on clinical features and laboratory assessments according to the clinical practice guidelines and a consensus statement [22, 23]. Three patients were excluded because they were diabetics on treatment with GLP-1 analogues and DPP4 inhibitors.

Exclusion criteria were pituitary radiotherapy treatment performed less than 5 years before pasireotide, pregnancy, women taking oral contraceptives, diabetes on GLP-1 analogues, DPP4 inhibitors or sulphonylurea treatment, intolerance to SSA, risk conditions for prolonged QT syndrome and severe liver or renal insufficiency.

Nine out of 12 patients were diabetics before recruitment. Diabetic patients with CD were on treatment with metformin, 7 out of 9 at the dose of $1000 \mathrm{mg} /$ day and 2 out of 9 at the dose of $1500 \mathrm{mg} /$ day. All diabetic patients with $\mathrm{CD}$ had stable glycaemic values (HbA1c $\leq 58 \mathrm{mmol} / \mathrm{mol}$ ) before pasireotide treatment.

To maintain stable glycaemic values during the study metformin and short-acting insulin were prescribed, even though it is different from what is currently recommended by the guidelines for the management of diabetes mellitus during pasireotide treatment [24]. However, we preferred not to use GLP-1 analogues and DPP-4 inhibitors, to avoid the interference of these drugs on clinical, metabolic parameters (insulin sensitivity) and adipokines [25-28].

According to UFC levels, evaluated as the average of three different collections, two patients were classified as having very mild [UFC $<1.5$ times the upper limit of the normal range (ULN)], seven patients as having mild (UFC $\geq 1.5$ and $\leq 2 \mathrm{ULN}$ ) $\mathrm{CD}$, two patients as having moderate (UFC $>2$ and $\leq 5$ ULN) and one patient as having a severe CD (UFC $>5$ ULN).

Patients were started on subcutaneous pasireotide therapy at the dose of $600 \mu \mathrm{g}$ twice daily, with increase to $900 \mu \mathrm{g}$ twice daily (bid), for those who did not have normalized mUFC levels after 3 months. At the 3-month follow-up, on the basis of the UFC levels, pasireotide dose was adjusted according to Italian rules for prescription and administration. In particular, patients with normal UFC levels continued the dose of $600 \mu \mathrm{g}$ bid, whereas those with still increased UFC levels received an uptitration of the drug dose to $900 \mu \mathrm{g}$ bid. In case of clinical or hormonal adrenal insufficiency as well as in case of drug intolerance, pasireotide was reduced by $300 \mu \mathrm{g}$ bid.

Pasireotide was delivered by the University of Palermo's Pharmacy, according to local policy. Pasireotide was delivered to each single patient. No incentives were given to patients for the current study.

The study protocol was approved by the Ethics Committee of the Policlinico Paolo Giaccone's Hospital, and a written informed consent was obtained from all patients.

At baseline and after 6 and 12 months of pasireotide treatment, clinical parameters such as BMI and waist circumference (WC) were measured at the midpoint between the lower rib and the iliac crest. After an overnight fast, lipids [total cholesterol (TC), HDL cholesterol, LDL cholesterol and triglycerides (TG)], HbA1c, glycaemia and insulinaemia were evaluated. The atherogenic index of plasma (AIP) was calculated as a log (TG/HDL-C). As hormonal parameters, we evaluated UFC as the mean of three 24-h urine collections (mUFC) and plasma ACTH. 
Basal insulin secretion was evaluated with HOMA- $\beta$ [(360× insulin)/(glucose -63) \% (glucose in mg/dl)] [29]. The stimulated insulin secretion was evaluated through the assessment of C-peptide levels during a liquid mixed meal tolerance test (MMTT). MMTT was performed using Ensure $6 \mathrm{ml} / \mathrm{kg}$ body weight with a maximum of $360 \mathrm{ml}$ (14 calories $/ \mathrm{ml} ; 57 \%$ carbohydrates, 28\% lipids and $15 \%$ protein). Blood samples were obtained at time 0 and then at 30,45, 60,90, and 120 min after the mixed meal. Samples were assayed for glucose and C-peptide. The trapezoidal method was used for calculation of the area under the curve for $\mathrm{C}$-peptide $\left(\mathrm{AUC}_{2 \mathrm{~h} \text { c-peptide }}\right)$ and glucose $\left(\mathrm{AUC}_{2 \mathrm{~h} \text { glycaemia }}\right)$.

Insulin sensitivity was indirectly estimated using basal insulin and glucose values to calculate the homeostatic model of insulin resistance (HOMA2-IR) [glycaemia $(\mathrm{mmol} / \mathrm{l}) \times$ insulinaemia $(\mathrm{mU} / \mathrm{ml}) / 22.5$ ] [29]. A euglycaemic hyperinsulinaemic clamp was also used to evaluate insulin sensitivity. One catheter was placed in a vein on the forearm for administration of insulin and glucose and the second catheter was placed in a vein of the contralateral forearm for blood samples. The clamp was performed under standard conditions, i.e. the plasma insulin concentration was acutely raised with insulin priming $(0-3 \mathrm{~min}$ : $113.6 \mathrm{mU} / \mathrm{m}^{2}, 3-6 \mathrm{~min}: 80.2 \mathrm{mU} / \mathrm{m}^{2}, 7-10 \mathrm{~min}: 50.4 \mathrm{mU} /$ $\mathrm{m}^{2}$ of body surface area) for the first $10 \mathrm{~min}$ of the test and maintained by continuous infusion of insulin infusion $\left(40 \mathrm{mU} / \mathrm{m}^{2}\right.$ for the remaining $\left.110 \mathrm{~min}\right)$. The rate of peripheral glucose utilization ( $M$ value) was calculated by dividing the glucose amount infused during the last 40 min by body weight measured in kilograms (milligrams per kilogram per minute). The plasma glucose concentration was held constant at basal levels by variable glucose infusion, and under the steady state conditions of euglycaemia the glucose infusion rate equalled glucose uptake by all the tissues in the body and it was therefore considered a measure of tissue sensitivity to exogenous insulin [30]. The plasma glucose level was clamped at $5 \mathrm{mmol} / \mathrm{L}$.

A panel of circulating adipokines including leptin, human leptin receptor $(\mathrm{Ob}-\mathrm{R})$, adiponectin, resistin, visfatin, adipocyte fatty acid binding protein (AFABP) and non-esterified fatty acids (NEFAs) were assayed before and after 12 months of pasireotide treatment.

All hypoglycaemic agents were discontinued $24 \mathrm{~h}$ before the metabolic evaluations, to avoid any interference in metabolic parameters.

The study was registered at clinicaltrials.gov, for adherence to clinical practice. The authors confirm that all ongoing and related trials for this drug are registered with the number NCT03080181.

\section{Safety analysis}

All the adverse events that occurred during the full period of treatment were registered for the safety analysis. The adverse events were classified as mild, moderate or severe on the basis of severity. The interventions performed for the adverse events were also registered during the full period of the study.

\section{Assays}

Insulin, glycaemia, C-peptide and lipids were measured by standard methods (Modular P800, Roche, Milan). LDL-C levels were measured using the Friedewald formula [total cholesterol - (HDL + (TG/5) ]. AIP was calculated as TG/HDL-C log. HbA1c levels were determined by HPLC with an ion-exchange resin (Bio-Rad Laboratories, Milan, Italy).

ACTH and UFC levels were detected by electrochemiluminescence immunoassay (ECLIA, Elecsys, Roche, Milan) following the manufacturer's instructions. Normal values for hormonal markers were defined as follows: ACTH 2.2-14 pmol/L and UFC 59-378 $\mathrm{nmol} / 24 \mathrm{~h}$.

Human leptin ( $\mathrm{ng} / \mathrm{ml})$, Ob-R $(\mathrm{ng} / \mathrm{ml})$, adiponectin $(\mu \mathrm{g} /$ $\mathrm{ml})$, resistin $(\mathrm{ng} / \mathrm{ml})$, visfatin $(\mathrm{ng} / \mathrm{ml})$ and AFABP $(\mathrm{ng} / \mathrm{ml})$ were assayed using an ELISA sandwich enzyme immunoassay (BioVendor, Heidelberg, Germany). NEFAs (mmol/L) were assayed by the colorimetric method (FA115, Randox Laboratories, County Antrim, UK).

The conversion factors for the International System (SI) were as follows: glucose $\mathrm{mg} / \mathrm{dl}$ vs. $\mathrm{mmol} / \mathrm{l}: 0.0555$; insulin $\mathrm{mUI} / \mathrm{ml}$ vs. pmol/l: 6.945; total cholesterol and HDL-C $\mathrm{mg} / \mathrm{dl}$ vs. mmol/l: 0.0259; triglycerides $\mathrm{mg} / \mathrm{dl}$ vs. $\mathrm{mmol} / \mathrm{l}$ : 0.0113 ; HbA1c \% vs mmol/mol: $10.93 \%$ - 23.5; cortisol $\mu \mathrm{g} / \mathrm{dl}$ vs. nmol/l: $27.59, \mathrm{UFC} \mu \mathrm{g} / 24 \mathrm{~h}$ vs. $\mathrm{nmol} / 24 \mathrm{h:} 2.76$; ACTH $\mathrm{pg} / \mathrm{ml}$ vs. pmol/l: 0.22 .

\section{Statistical analysis}

The Statistical Packages for Social Science (SPSS) version 17 (SPSS, Inc.) was used for data analysis "intention to treat". The analysis was performed at the group level. The normality of quantitative variables was tested with the Shapiro-Wilk test. Data were presented as the median and interquartile ranges for continuous variables. A Friedman analysis was performed to compare the numerical variables at baseline, 6-, and 12-month follow-up. A Wilcoxon analysis for circulating adipokines was carried out. Simple univariate correlations among continuous variables with nonnormal distribution were determined by Spearman's test. A $p$ value $<0.05$ was considered to be statistically significant. 


\section{Results}

Of a total of 12 patients who were eligible for the study, all were assigned to pasireotide treatment. No patients withdrew from the study. All patients were analysed. No protocol deviations were recorded (Fig. 1).

Nine out of 12 patients had normalization of mUFC levels with the dose of $600 \mu \mathrm{g}$ of pasireotide. One patient had normalized mUFC levels with a dose of $900 \mu \mathrm{g}$.

Two patients did not have normalization of mUFC levels, despite the increase in dose to $900 \mu \mathrm{g}$. One of them, who had moderate $\mathrm{CD}$, had a decrease of approximately $60 \%$, while the other one, who had severe $\mathrm{CD}$, had a decrease of about $55 \%$, compared to baseline.
The most frequent adverse event of the pasireotide treatment was hyperglycaemia. At the end of the study, 11 out of 12 patients had diabetes mellitus, even though 9 out of 12 were diabetic before pasireotide therapy. 2 out of 12 patients who developed diabetes mellitus during pasireotide treatment were females with a family history of diabetes, aged more than 50 years and obese (BMI 38.6 and $42.5 \mathrm{~kg} / \mathrm{m}^{2}$, respectively). On the other hand, the patient who did not develop diabetes was a 40-year-old man without family history of diabetes and overweight (BMI $28.6 \mathrm{~kg} / \mathrm{m}^{2}$ ).

After 1 month of pasireotide treatment, in nine patients who were diabetic before therapy, metformin was increased at the dose of $2000 \mathrm{mg} / \mathrm{day}$, while in the two patients who developed diabetes during pasireotide treatment metformin was started at the dose of $1000 \mathrm{mg} /$ day.

\section{Flow Diagram}

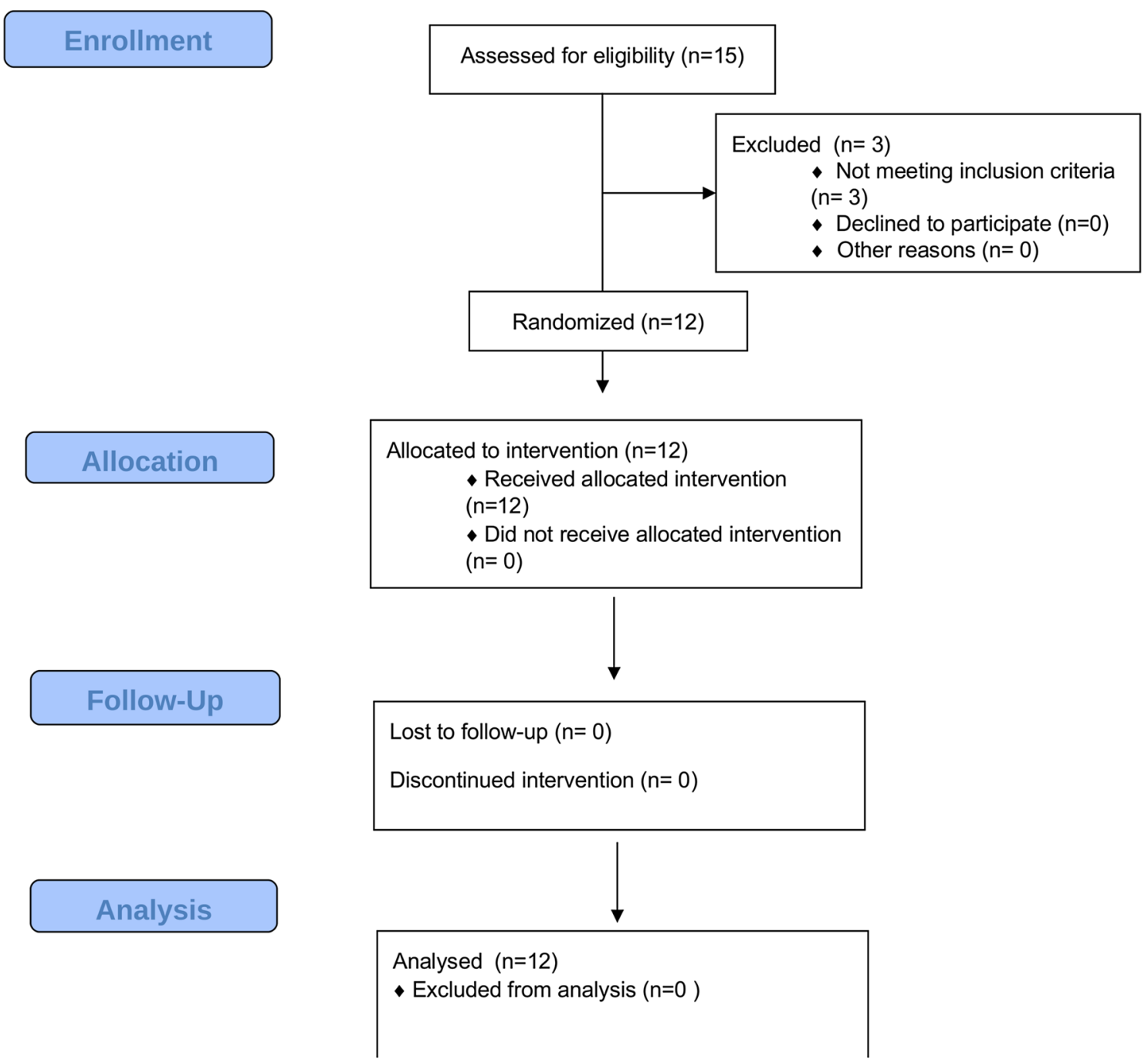

Fig. 1 A flowchart of patient disposition at enrolment, allocation, follow-up and analysis according to CONSORT flow diagram 
After 3 months, 2 out of 11 patients were on combined metformin $(2550 \mathrm{mg} /$ day $)$ and short-acting insulin therapy, while 9 out of 11 were treated with metformin alone at the dose of $2550 \mathrm{mg} /$ day. After 6 months of pasireotide, 3 out of 11 patients were treated with short-acting insulin and metformin $(2550 \mathrm{mg} /$ day $)$. This anti-diabetic treatment was maintained until the end of the study.

Ten out of 12 patients experienced grade 2 nausea and diarrhoea as adverse events. The duration of adverse event was no longer than 6 months and gradually reduced during the treatment. Less frequently, meteorism in two (16\%), asthenia in one $(8.3 \%)$ and irritability and articular pain in one $(8.3 \%)$ patient have also been described.
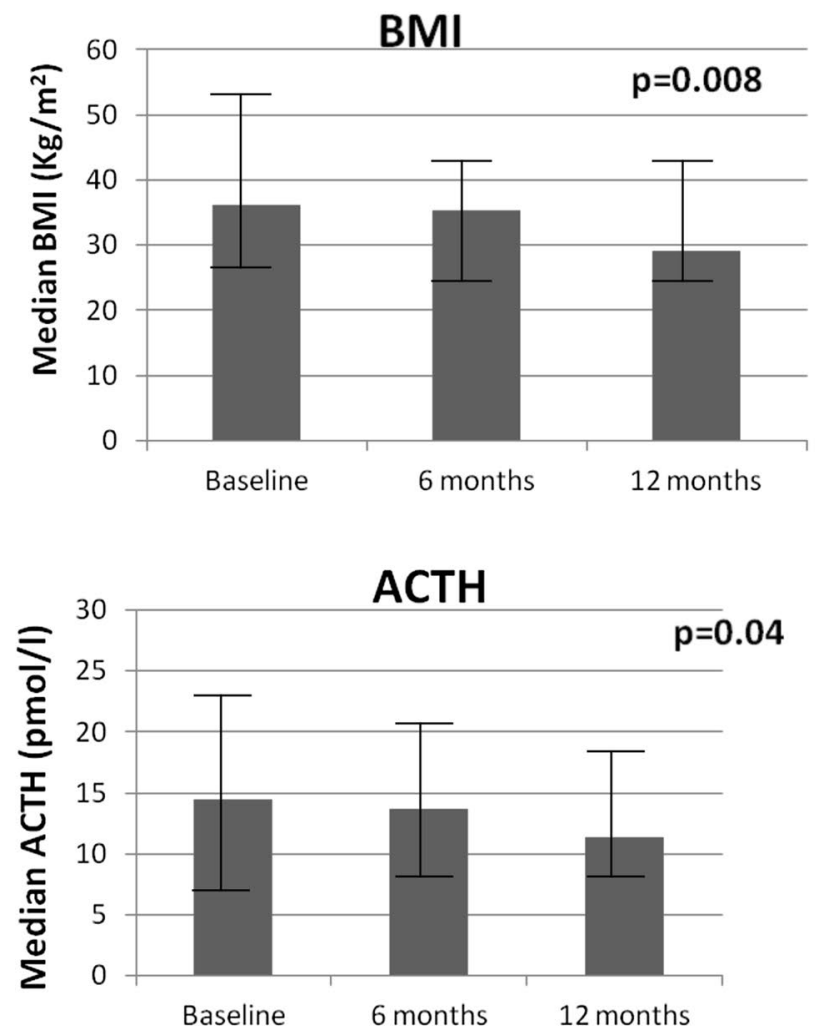

\section{Clinical and hormonal profile}

During pasireotide treatment, a significant decrease in weight $(p=0.004)$, BMI $(p=0.008)$, WC $(p=0.009)$ and mUFC ( $p=0.007)$ was found. A significant change in ACTH levels was found during the follow-up $(p=0.049)$ (Fig. 2). No significant differences were found on comparing patients treated with metformin alone and patients treated with combined metformin and short-acting insulin (data not shown).
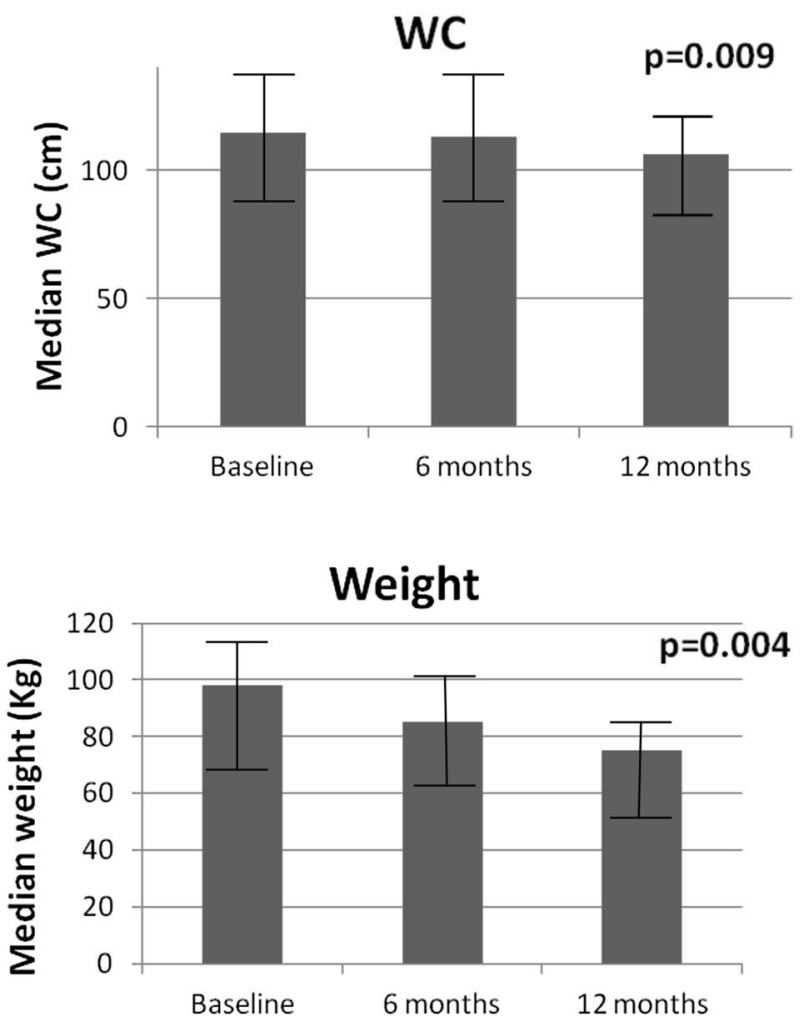

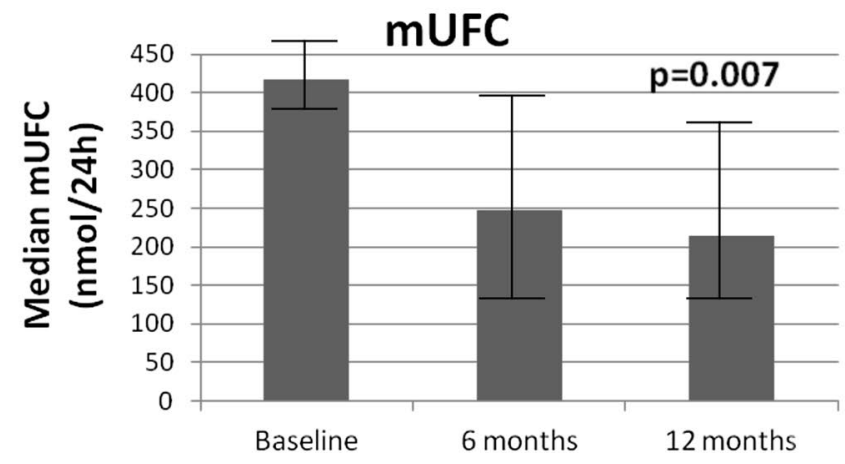

Fig. 2 Clinical, weight, BMI and waist circumference (WC) and hormonal parameters, ACTH and mUFC in patients with Cushing's disease before and after 6 and 12 months of pasireotide treatment. Data are expressed as median and interquartile range 


\section{Metabolic parameters}

During treatment, a significant increase in fasting glycaemia $(p=0.015)$, HbAlc levels $(p=0.030)$ and $\mathrm{AUC}_{2 \mathrm{~h} \text { glycaemia }}$ $(p=0.007)$ was found (Table 1). No significant change in lipid profile was found (Table 1). Similarly, no significant correlation between mUFC and metabolic parameters was found (data not shown).

With regard to insulin secretion, a significant decrease in HOMA- $\beta(p=0.015)$, fasting insulinaemia $(p=0.007)$ and $\operatorname{AUC}_{2 \mathrm{~h} \text { c-peptide }}(p=0.017)$ was found during 12 months of treatment (Table 1), while no significant difference in insulin sensitivity indexes was observed. No differences in insulin sensitivity and secretion parameters were found in patients treated at the dose of 600 or $900 \mu \mathrm{g}$ twice daily of pasireotide (Table 2) and in patients treated with metformin alone and with combined metformin and short-acting insulin (Table 3). No significant correlation between mUFC and the insulin secretion and sensitivity parameters was found (Fig. 3).

\section{Adipokine profile}

After 12 months of treatment, a significant decrease in leptin [15.5 (8.9-54.3) vs. 30.2 (11-59.6) ng/ml; $p=0.039]$, leptin/ Ob-R ratio [2.5 (0.25-7.54) vs. $0.66(0.32-3.82) ; p=0.017]$ and AFABP [82.9 (11.2-137.3) vs. 41.7 (18.6-66.3) ng/ $\mathrm{ml} ; p=0.036]$ and a concomitant increase in Ob-R [15.4 (7.1-40.5) vs. $23.9(11.9-51) \mathrm{ng} / \mathrm{ml} ; p=0.028]$ was found compared to baseline levels (Table 4). No significant change in adiponectin, resistin, visfatin and NEFAs was observed (Table 4).

Table 1 Metabolic parameters during 12 months of pasireotide treatment in patients with Cushing's disease

\begin{tabular}{|c|c|c|c|c|}
\hline & $\begin{array}{l}\text { Baseline } \\
\text { Median (IR) }\end{array}$ & $\begin{array}{l}6 \text { months } \\
\text { Median (IR) }\end{array}$ & $\begin{array}{l}12 \text { months } \\
\text { Median (IR) }\end{array}$ & $p$ \\
\hline Fasting glycaemia (mmol/l) & $5.22(4.05-6.11)$ & $7.4(4.18-9.2)$ & $8.07(4.27-8.88)$ & 0.015 \\
\hline $\mathrm{HbA} 1 \mathrm{c}(\mathrm{mmol} / \mathrm{mol})$ & $43(32-53)$ & $46(33-58)$ & $50(32-58)$ & 0.030 \\
\hline $\mathrm{AUC}_{2 \mathrm{~h} \text { glycaemia }}(\mathrm{mmol} / \mathrm{l} 120 \mathrm{~min})$ & $767(577.7-927.4)$ & $1110(578-1171)$ & $1331(412.9-1564.2)$ & 0.007 \\
\hline Fasting insulinaemia (pmol/L) & $46.2(27-97.9)$ & $31.5(17-55)$ & $26.8(15-48.7)$ & 0.007 \\
\hline HOMA $\beta$ & $72.8(56.1-221.7)$ & $44.7(31.6-116.8)$ & $36.3(29.2-105.6)$ & 0.015 \\
\hline $\mathrm{AUC}_{2 \mathrm{~h} \text { c-peptide }}(\mathrm{nmol} / \mathrm{l} 120 \mathrm{~min})$ & $205.7(196.4-348.1)$ & $166(155-298)$ & $160.9(149.5-284.5)$ & 0.017 \\
\hline HOMA2-IR & $0.89(0.51-1.71)$ & $0.96(0.61-1.62)$ & $0.98(0.63-1.6)$ & 0.368 \\
\hline$M$ value & $2.26(0.45-4.8)$ & $1.93(0.23-2.14)$ & $1.61(0.19-3.2)$ & 0.472 \\
\hline Total cholesterol (mmol/l) & $5.37(4.63-6.72)$ & $5.2(4.5-6.5)$ & $5.1(4.5-5.9)$ & 0.065 \\
\hline HDL cholesterol (mmol/l) & $1.6(0.67-2.24)$ & $1.64(0.8-2.25)$ & $1.68(0.93-2.32)$ & 0.176 \\
\hline Triglycerides (mmol/l) & $1.15(0.84-2.49)$ & $1.05(0.7-2.28)$ & $0.99(0.44-2.10)$ & 0.050 \\
\hline LDL cholesterol (mmol/l) & $3.12(2.2-4.3)$ & $2.8(2.4-4.1)$ & $2.76(2.37-3.37)$ & 0.050 \\
\hline Atherogenic index (AIP) & $-0.16(-0.39$ to 0.72$)$ & $-0.17(-0.3$ to 0.11$)$ & $-0.18(-0.25$ to 0.15$)$ & 0.068 \\
\hline
\end{tabular}

Table 2 Comparison of insulin secretion and sensitivity parameters between patients with Cushing's disease treated with pasireotide 600 and $900 \mu \mathrm{g}$ twice daily after 6 and 12 months

\begin{tabular}{|c|c|c|c|c|c|c|}
\hline & $\begin{array}{l}\text { Patients treated with } \\
\text { pasireotide } 600 \mu \mathrm{g} \\
\text { twice daily at } 6 \text { months } \\
(N=9) \\
\text { Median (IR) }\end{array}$ & $\begin{array}{l}\text { Patients treated with } \\
\text { pasireotide } 900 \mu \mathrm{g} \\
\text { twice daily at } 6 \text { months } \\
(N=3) \\
\text { Median (IR) }\end{array}$ & $p^{*}$ & $\begin{array}{l}\text { Patients treated with } \\
\text { pasireotide } 600 \mu \mathrm{g} \text { twice } \\
\text { daily at } 12 \text { months } \\
(N=9) \\
\text { Median (IR) }\end{array}$ & $\begin{array}{l}\text { Patients treated with } \\
\text { pasireotide } 900 \mu \mathrm{g} \text { twice } \\
\text { daily at } 12 \text { months } \\
(N=3) \\
\text { Median (IR) }\end{array}$ & $p^{* *}$ \\
\hline $\begin{array}{l}\text { Fasting insulinaemia } \\
(\mathrm{pmol} / \mathrm{L})\end{array}$ & $54.1(27.7-124.3)$ & $65.2(31.2-78.4)$ & 0.926 & $54.1(34-82.6)$ & $61.1(27.8-75.7)$ & 0.405 \\
\hline НОМА $\beta$ & $50(15.8-132.3)$ & $34.6(31.7-77.7)$ & 0.518 & $44.7(31.8-105.6)$ & $29.2(31.4-58.5)$ & 0.116 \\
\hline $\begin{array}{l}\mathrm{AUC}_{2 \mathrm{~h} \mathrm{c} \text {-peptide }}(\mathrm{nmol} / \mathrm{l} \\
120 \mathrm{~min})\end{array}$ & $564(270.9-796.8)$ & $574.5(514.5-586.5)$ & 0.926 & $432(408-643.3)$ & $504(477-529.8)$ & 0.518 \\
\hline HOMA2-IR & $1.05(0.61-2.48)$ & $1.39(0.64-1.54)$ & 0.926 & $1.1(0.63-1.6)$ & $0.9(0.42-1.36)$ & 0.517 \\
\hline M value & $2(1.42-3.8)$ & $1.93(0.23-2.14)$ & 0.781 & $1.98(1.23-2.3)$ & $1.6(1.55-2.1)$ & 0.515 \\
\hline
\end{tabular}

* $p$ comparison between patients treated with pasireotide 600 and $900 \mu \mathrm{g}$ twice daily after 6 months

** $p$ comparison between patients treated with pasireotide 600 and $900 \mu \mathrm{g}$ twice daily after 12 months 
Table 3 Comparison of insulin secretion and sensitivity parameters between patients with Cushing's disease treated with metformin alone and with combined metformin and short-acting insulin after 6 and 12 months of pasireotide treatment

\begin{tabular}{|c|c|c|c|c|c|c|}
\hline & $\begin{array}{l}\text { Patients treated with } \\
\text { metformin alone at } \\
6 \text { months }(N=8)\end{array}$ & $\begin{array}{l}\text { Patients treated } \\
\text { with metformin and } \\
\text { short-acting insulin at } \\
6 \text { months }(N=3)\end{array}$ & $p^{*}$ & $\begin{array}{l}\text { Patients treated with } \\
\text { metformin alone at } \\
12 \text { months }(N=8)\end{array}$ & $\begin{array}{l}\text { Patients treated } \\
\text { with metformin and } \\
\text { short-acting insulin } \\
\text { at12 months }(N=3)\end{array}$ & $p^{* *}$ \\
\hline & Median (IR) & Median (IR) & & Median (IR) & Median (IR) & \\
\hline $\begin{array}{l}\text { Fasting insulinaemia } \\
(\mathrm{pmol} / \mathrm{L})\end{array}$ & $59.8(27.8-124.3)$ & $57.6(31.2-78.4)$ & 0.838 & $52.7(37.5-82.6)$ & $55.5(20.1-67.3)$ & 0.919 \\
\hline НОМА $\beta$ & $43.4(15.8-132.3)$ & $50(28.7-77.7)$ & 0.838 & $36.3(29.2-105.6)$ & $44.7(21.4-58.5)$ & 0.683 \\
\hline $\begin{array}{l}\mathrm{AUC}_{2 \mathrm{~h} \text { c-peptide }}(\mathrm{nmol} / \mathrm{l} \\
120 \mathrm{~min})\end{array}$ & $575.2(270.9-796.8)$ & $527.8(514.5-574.5)$ & 0.683 & $478.6(408-643.3)$ & 477 (432-504) & 0.989 \\
\hline HOMA2-IR & $1.22(0.81-2.48)$ & $1.17(0.64-1.54)$ & 0.683 & $1.08(0.77-1.6)$ & $1.18(0.42-1.36)$ & 0.919 \\
\hline$M$ value & $1.88(1.23-3.8)$ & $1.98(1.42-2.3)$ & 0.919 & $1.52(0.19-3.2)$ & $1.6(0.4-2.1)$ & 0.759 \\
\hline
\end{tabular}

* $p$ comparison between patients treated with metformin alone and combined with short-acting insulin after 6 months of pasireotide

**p comparison between patients treated with metformin alone and combined with short-acting insulin after 12 months of pasireotide
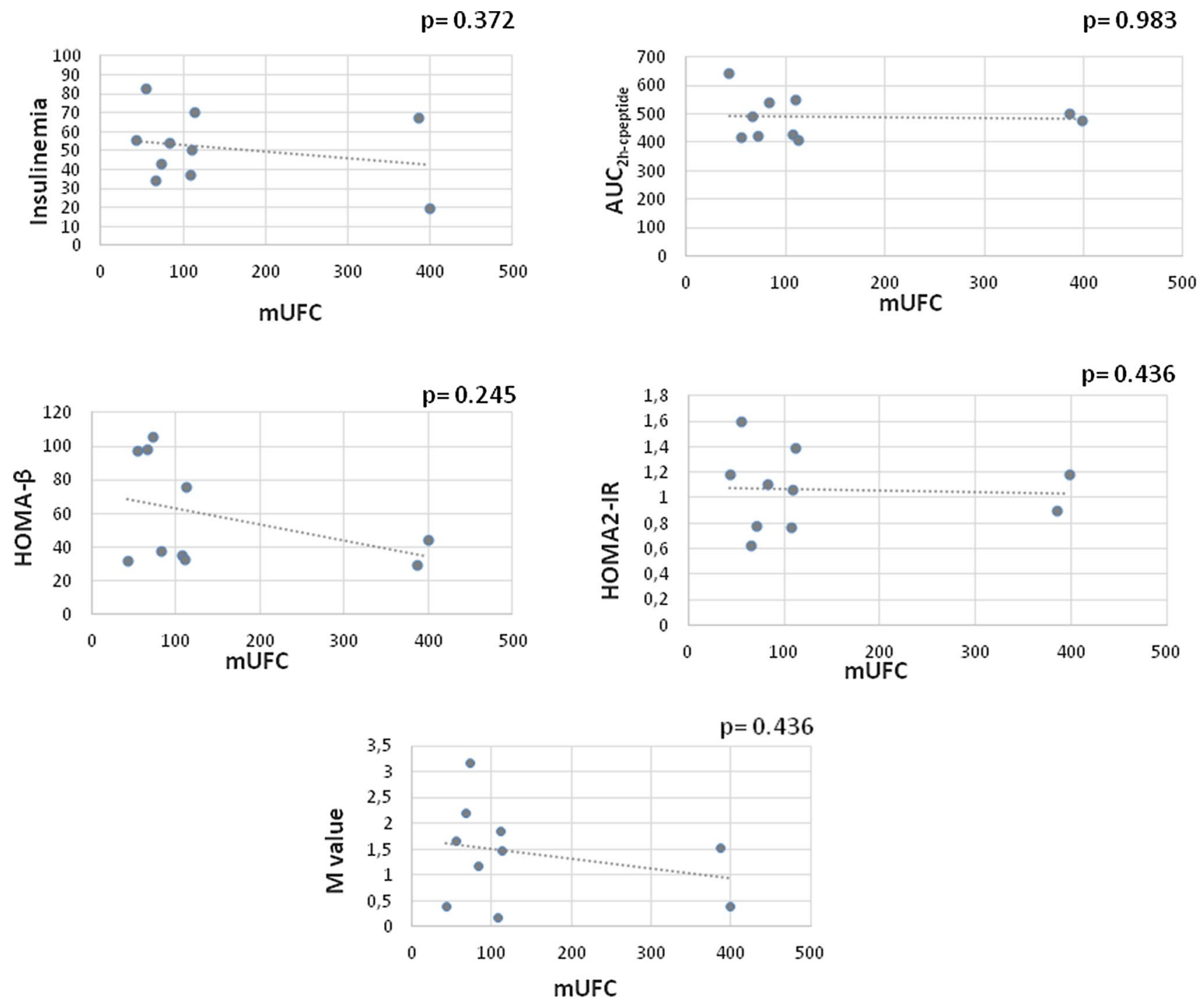

Fig. 3 Correlation among UFC and insulin secretion and sensitivity parameters after 12 months of treatment with pasireotide 
Table 4 Adipokine levels in patients with Cushing's disease $(\mathrm{CD})$ at baseline and after 12 months of pasireotide treatment

\begin{tabular}{llll}
\hline & $\begin{array}{l}\text { Patients with CD at base- } \\
\text { line }(N=12) \\
\text { Median (IR) }\end{array}$ & $\begin{array}{l}\text { Patients with CD after 12 months of } \\
\text { pasireotide }(N=12) \\
\text { Median (IR) }\end{array}$ & $p$ \\
\hline Leptin $(\mathrm{ng} / \mathrm{ml})$ & $30.2(11-59.6)$ & $15.5(8.9-54.3)$ & 0.039 \\
Ob-R $(\mathrm{ng} / \mathrm{ml})$ & $15.4(7.1-40.5)$ & $23.9(11.9-51)$ & 0.028 \\
Leptin/Ob-R ratio & $2.5(0.25-7.54)$ & $0.66(0.32-3.82)$ & 0.017 \\
Adiponectin $(\mu \mathrm{g} / \mathrm{ml})$ & $8.7(6.29-17.4)$ & $12.2(5.58-14.5)$ & 0.889 \\
Resistin $(\mathrm{ng} / \mathrm{ml})$ & $6.3(4.13-14.3)$ & $4.15(3.33-10.1)$ & 0.161 \\
Visfatin $(\mathrm{ng} / \mathrm{ml})$ & $1.41(0.32-3.6)$ & $1.73(0.12-6.49)$ & 0.400 \\
AFABP $(\mathrm{ng} / \mathrm{ml})$ & $82.9(11.2-137.3)$ & $41.7(18.6-66.3)$ & 0.036 \\
NEFAs $(\mathrm{ng} / \mathrm{ml})$ & $1.09(0.58-1.76)$ & $0.86(0.21-1.25)$ & 0.208 \\
\hline
\end{tabular}

We did not find significant differences in leptin, leptin/ $\mathrm{Ob}-\mathrm{R}$ ratio, AFABP and $\mathrm{Ob}-\mathrm{R}$ in the two patients who did not have normalized UFC after 12 months of pasireotide treatment. In addition, we also compared patients treated with metformin alone and with combined metformin and short-acting insulin, and no significant differences were found (data not shown).

After 12 months of pasireotide treatment, leptin showed a significant positive correlation with BMI $(p=0.002 ; \mathrm{r}$ $0.905)$, WC ( $p=0.007 ; r 0.857), \mathrm{AUC}_{2 \text { hglycaemia }}(p=0.007$; $r$ 0.857) and $\mathrm{ACTH}(p=0.028 ; r 0.762)$ and an inverse correlation with HOMA- $\beta$ ( $p=0.004 ; r-0.881)$ (Table 5). Ob-R showed a positive correlation with HbA1c $(p=0.028$; $r$ 0.762) (Table 5). The leptin/Ob-R ratio showed a positive correlation with $\mathrm{AUC}_{2 \mathrm{~h} \text { c-peptide }}(p=0.010 ; r 0.833)$ and ACTH ( $p=0.037 ; r 0.738)$ (Table 5). AFABP showed a positive correlation with BMI $(p=0.002 ; r 0.905)$, WC $(p=0.007 ; r 0.857)$, ACTH $(p=0.017 ; r 0.802)$, AUC 2h glycaemia $(p<0.001 ; r$ 0.952) and HbA1c $(p=0.047 ; r$ 0.714 ) (Table 3 ), while it inversely correlated with HOMA- $\beta$ $(p=0.001 ; r-0.929)$ (Table 5). No differences in adipokine levels was found in patients treated at the dose of 600 or $900 \mu \mathrm{g}$ twice daily of pasireotide and no significant correlation between mUFC and adipokines was found (data not shown).

\section{Discussion}

In this study, performed in a small cohort of patients with active $C D$, we showed that 12 months of pasireotide treatment is associated with a significant impairment of glucose metabolism and insulin secretion, without any significant change in insulin sensitivity and an improvement of the adipokine profile.

The current study reported a good control of cortisol secretion. Ten out of 12 patients had full normalization of UFC levels, while 2 patients were partially responsive to the treatment. These results appear to be in disagreement with those of the phase-III study, which reported $34.2 \%$ of full and partial control of cortisol levels [8]. However, the phase-III study included $78 \%$ of patients with moderate to
Table 5 Bivariate correlations among adipokines and clinical, hormonal and metabolic indexes in patients with Cushing's disease

\begin{tabular}{|c|c|c|c|c|c|c|c|c|}
\hline & \multicolumn{2}{|l|}{ Leptin } & \multicolumn{2}{|l|}{ Ob-R } & \multicolumn{2}{|c|}{ Leptin/Ob-R ratio } & \multicolumn{2}{|l|}{ AFABP } \\
\hline & $r$ & $p$ & $r$ & $p$ & $r$ & $p$ & $r$ & $p$ \\
\hline \multicolumn{9}{|c|}{ Clinical parameters } \\
\hline BMI & 0.905 & 0.002 & 0.143 & 0.736 & 0.643 & 0.086 & 0.905 & 0.002 \\
\hline WC & 0.857 & 0.007 & 0.238 & 0.570 & 0.619 & 0.102 & 0.857 & 0.007 \\
\hline \multicolumn{9}{|c|}{ Hormonal parameters } \\
\hline $\mathrm{ACTH}$ & 0.762 & 0.028 & -0.167 & 0.693 & 0.738 & 0.037 & 0.802 & 0.017 \\
\hline mUFC & 0.048 & 0.911 & 0.690 & 0.058 & -0.357 & 0.385 & 0.286 & 0.493 \\
\hline \multicolumn{9}{|c|}{ Metabolic parameters } \\
\hline $\mathrm{HbA} 1 \mathrm{c}$ & 0.524 & 0.183 & 0.762 & 0.028 & -0.048 & 0.911 & 0.714 & 0.047 \\
\hline $\mathrm{AUC}_{2 \mathrm{~h} \text {-glycaemia }}$ & 0.857 & 0.007 & 0.429 & 0.289 & 0.262 & 0.531 & 0.952 & $<0.001$ \\
\hline $\mathrm{AUC}_{2 \mathrm{~h} \text {-c-peptide }}$ & 0.667 & 0.071 & -0.381 & 0.352 & 0.833 & 0.010 & 0.476 & 0.233 \\
\hline НОМА- $\beta$ & -0.881 & 0.004 & -0.429 & 0.289 & -0.214 & 0.610 & -0.929 & 0.001 \\
\hline HOMA2-IR & 0.690 & 0.058 & 0 & 1 & 0.452 & 0.260 & 0.524 & 0.183 \\
\hline$M$ value & -0.405 & 0.320 & -0.381 & 0.352 & -0.286 & 0.493 & -0.476 & 0.233 \\
\hline
\end{tabular}


severe $\mathrm{CD}$, while the current study focused on patients with very mild and mild disease, who might appear as the patients with the highest benefit from pasireotide therapy. Indeed, the chance inclusion of patients with less severe disease is probably responsible for the increase of positive response rate of $88 \%$ and this rate is much better than reported in daily clinical practice studies [11].

Despite proper diabetes control at baseline, all patients except one experienced an increase in fasting blood glucose and $\mathrm{HbA} 1 \mathrm{c}$ after pasireotide treatment, even though metformin and short-acting insulin were able to maintain a fair glycaemic control. The impairment of glycaemic values was not pasireotide dose dependent.

As a well-known effect of pasireotide, a strong decrease in insulin secretion was observed [13, 31]. Notably, it was associated with a concomitant and proportional significant decrease in C-peptide levels evaluated after MMTT stimulation.

Interestingly, we did not observe any change in insulin sensitivity, as might be expected. Probably, the lack of improvement in insulin resistance, despite the glucocorticoid control and the significant weight loss, along with the inhibition of insulin release might be the crucial factors for hyperglycaemia.

In addition, we aimed to evaluate the effect of pasireotide treatment on adipose function by circulating adipokines. We studied the ability of many common anthropometric, hormonal and metabolic parameters to correlate with a wide panel of adipokines. Though the literature data show a continued involvement of new adipokines, we chose to study some of those that have more scientific evidence about their ability to express a condition of adipose tissue dysfunction [32].

Data on adipokines in CS tend to show that altered production of adipokines is linked to visceral adiposity more than to cortisol levels [33]. Leptin has an endocrine function in body weight regulation and it has been shown to be elevated in patients with active CS [34,35]. In the current study, after 12 months of pasireotide, a reduction in leptin was observed, with a positive correlation with BMI, $\mathrm{WC}, \mathrm{ACTH}$ and $\mathrm{AUC}_{2 \mathrm{hglycaemia}}$, and inverse correlation with HOMA- $\beta$.

These data tend to suggest that the body weight decrease, the hormonal levels and the insulin secretion are strictly related to leptin. Previous studies have showed that the decrease in leptin levels after correction of hypercortisolism seemed to be dependent on the evaluation time (i.e. shortterm vs. long-term after remission) and changes in body fat [36]. However, patients with CD maintain high leptin levels also after both decrease and normalization of cortisol levels and weight decrease, suggesting the role of other factors interplaying in this network.

An increase in Ob-R levels and a decrease in leptin/Ob-R ratio were observed after 12 months of pasireotide. $\mathrm{Ob}-\mathrm{R}$ was found to positively correlate with $\mathrm{HbA} 1 \mathrm{c}$, while leptin/ $\mathrm{Ob}-\mathrm{R}$ ratio was found to be positively correlated with $\mathrm{ACTH}$ and $\mathrm{AUC}_{2 \mathrm{~h} \text { c-peptide. }}$ As known, $\mathrm{Ob}-\mathrm{R}$ is also expressed in pancreatic $\beta$-cells and the binding of leptin to its receptor is linked to a decrease in insulin secretion.

No significant differences in resistin, visfatin and NEFAs levels were found after 12 months of pasireotide, compared to baseline, despite the control of hypercortisolism. With regard to adiponectin, a trend of increase in adiponectin was observed, even though it was not significant, maybe due to the small number of patients enrolled. However, the absence of change of resistin, visfatin and adiponectin, despite the control of hypercortisolism, is in line with previous studies [37, 38].

Circulating levels of AFABP are reported to be strongly positively linked to BMI, blood glucose and glycated haemoglobin levels in patients with type 2 diabetes mellitus and have an inverse relationship with the parameters of insulin sensitivity measured by the isoglycaemic hyperinsulinaemic clamp [39]. After 12 months of pasireotide, a strong decrease in AFABP levels was observed. At univariate analysis, we found a positive correlation between AFABP and clinical parameters (BMI and WC), hormonal parameters (ACTH) and metabolic parameters $\left(\mathrm{AUC}_{2 \mathrm{~h} \text {-glycaemia }}\right.$ and $\left.\mathrm{HbA1c}\right)$ and an inverse correlation with HOMA $\beta$.

The data of the current study confirm those of previous studies, with regard to the effects of pasireotide on insulin secretion [13]. However, we believe that the strength of the study lies in use of the two gold standard tests to evaluate insulin sensitivity and secretion, i.e. the euglycaemic hyperinsulinaemic clamp and the MMTT, respectively, in concomitance with evaluation of a panel of circulating adipokines as markers of adipose tissue function. It is well known that $\beta$-cell function cannot be accurately estimated on the basis of the endogenous insulin levels because of the pulsate release pattern and the short half-life. A more accurate estimation could be provided by C-peptide, a by-product of insulin production with a half-life of $30 \mathrm{~min}$. Since insulin and C-peptide are co-secreted by $\beta$-cells on an equimolar basis, the stimulated secretion of C-peptide is widely accepted as a measure of $\beta$-cell function [40-42]. As far as we know, this is the first study to evaluate insulin secretion through the measurement of C-peptide levels in CD.

However, some limitations of the study should be considered. It was performed on a small cohort of CD patients, though the number was in line with that of other published monocentric studies on patients with $\mathrm{CD}$ treated by pasireotide.

Another limitation is that almost all patients had a previous diagnosis of diabetes and glucose lowering therapy was suspended just for a short term, to avoid an increase of glycaemic values. Indeed, the evaluation of $\beta$-cell and adipose function also in patients without overt diabetes 
could be useful to better understand the effect of pasireotide treatment. The impact of metformin on adipokines levels is not clearly established, as a recent meta-analysis has demonstrated that metformin treatment was not associated with a decrease of leptin levels compared to placebo [43]. On the other hand, the effect of metformin on insulin sensitivity and weight decrease has been clearly established [44].

In addition, it seems difficult to separate the direct from indirect effect, mediated by a change in cortisol levels, of pasireotide on glucose metabolism and adipose tissue function. Moreover, other factors interplaying in the glucose metabolism, such as glucagon, GLP-1 and GIP, were not evaluated in the current study.

In conclusion, these preliminary data confirm that pasireotide treatment results in good cortisol secretion control, though it is associated with a decline in insulin secretion and in the persistence of insulin resistance, leading to a worsening of hyperglycaemia in diabetic patients, though its effect is not dose dependent. The hyperglycaemic effect of pasireotide is probably a consequence of a direct effect on beta-cells, though not all patients on pasireotide treatment develop diabetes. We hypothesize that family history of diabetes, gender, age, lifestyle and other metabolic factors may influence the onset of diabetes in a patient with $\mathrm{CD}$ who starts pasireotide treatment.

The reduction of cortisol levels leads to the well-known decrease in visceral obesity, while for the first time in this setting we showed a significant variation in some circulating adipokines involved in insulin resistance and cardiovascular risk.

Interestingly, leptin appears to be the most useful index of metabolic alterations, such as insulin secretion and adipose dysfunction. Leptin may be a marker of persistence of cardiometabolic risk in patients with $\mathrm{CD}$ and might reflect the residual cardiovascular risk despite the normalization of clinical and hormonal parameters. Therefore, the role of adipokines in the clinical and metabolic features of patients on pasireotide treatment needs to be further investigated by other prospective studies performed on a larger cohort of patients.

Acknowledgements We are grateful to Dr. Marco Calogero Amato, who died before the submission of the paper, for his contribution in the performance of the clamp procedure.

\section{Compliance with ethical standards}

Conflict of interest The authors declare that they have no conflict of interest.

Ethical approval All procedures performed in studies involving human participants were in accordance with the ethical standards of the institutional and/or national research committee and with the 1964 Helsinki Declaration and its later amendments or comparable ethical standards.
Informed consent Informed consent was obtained from all individual participants included in the study.

\section{References}

1. Graversen D, Vestergaard P, Stochholm K, Gravholt CH, Jørgensen JO (2002) Mortality in Cushing's syndrome: a systematic review and meta-analysis. Eur J Intern Med 23:278-282

2. Patil CG, Prevedello DM, Lad SP, Vance ML, Thorner MO, Katznelson L et al (2008) Late recurrences of Cushing's disease after initial successful transsphenoidal surgery. J Clin Endocrinol Metab 93:358-362

3. Vance ML (2009) Cushing's disease: radiation therapy. Pituitary 12:11-14

4. Ritzel K, Beuschlein F, Mickisch A, Osswald A, Schneider HJ, Schopohl J et al (2013) Clinical review: outcome of bilateral adrenalectomy in Cushing's syndrome: a systematic review. J Clin Endocrinol Metab 98:3939-3948

5. Nieman LK, Biller BM, Findling JW, Murad MH, Newell-Price J, Savage MO, Endocrine Society et al (2015) Treatment of Cushing's syndrome: an endocrine society clinical practice guideline. J Clin Endocrinol Metab 100:2807-2831

6. Pivonello R, De Martino MC, Cappabianca P, De Leo M, Faggiano A, Lombardi G et al (2009) The medical treatment of Cushing's disease: effectiveness of chronic treatment with the dopamine agonist cabergoline in patients unsuccessfully treated by surgery. J Clin Endocrinol Metab 94:223-230

7. Boscaro M, Ludlam WH, Atkinson B, Glusman JE, Petersenn S, Reincke $\mathrm{M}$ et al (2009) Treatment of pituitary-dependent Cushing's disease with the multireceptor ligand somatostatin analog pasireotide (SOM230): a multicenter, phase II trial. J Clin Endocrinol Metab 94:115-122

8. Colao A, Petersenn S, Newell-Price J, Findling JW, Gu F, Maldonado $\mathrm{M}$ et al (2012) A 12-month phase 3 study of pasireotide in Cushing's disease. N Engl J Med 366:914-924

9. Schopohl J, Gu F, Rubens R, Van Gaal L, Bertherat J, LiguerosSaylan M et al (2015) Pasireotide can induce sustained decreases in urinary cortisol and provide clinical benefit in patients with Cushing's disease: results from an open-ended, open-label extension trial. Pituitary 18:604-612

10. Guarnotta V, Ciresi A, Pitrone M, Pizzolanti G, Giordano C (2017) Pasireotide versus pituitary surgery: a retrospective analysis of 12 months of treatment in patients with Cushing's disease. Endocrine. https://doi.org/10.1007/s12020-017-1276-7

11. Trementino L, Michetti G, Angeletti A, Marcelli G, Concettoni C, Cardinaletti C et al (2016) Single-center 10-year experience with pasireotide in Cushing's disease: patients' characteristics and outcome. Horm Metab Res 48:290-298

12. Webb SM, Ware JE, Forsythe A, Yang M, Badia X, Nelson LM, Signorovitch JE, McLeod L, Maldonado M, Zgliczynski W, de Block C, Portocarrero-Ortiz L, Gadelha M (2014) Treatment effectiveness of pasireotide on health-related quality of life in patients with Cushing's disease. Eur J Endocrinol 171:89-98

13. Henry RR, Ciaraldi TP, Armstrong D, Burke P, Ligueros-Saylan M, Mudaliar S (2013) Hyperglycemia associated with pasireotide: results from a mechanistic study in healthy volunteers. J Clin Endocrinol Metab 98:3446-3453

14. Giordano C, Guarnotta V, Pivonello R, Amato MC, Simeoli C, Ciresi A et al (2013) Is diabetes in Cushing's syndrome only a consequence of hypercortisolism? Eur J Endocrinol 170:311-319

15. Guarnotta V, Amato MC, Pivonello R, Arnaldi G, Ciresi A, Trementino L et al (2017) The degree of urinary hypercortisolism 
is not correlated with the severity of cushing's syndrome. Endocrine 55:564-572

16. Yamashita S, Nakamura T, Shimomura I, Nishida M, Yoshida S, Kotani K et al (1996) Insulin resistance and body fat distribution. Diabetes Care 19:287-291

17. Amato MC, Guarnotta V, Giordano C (2013) Body composition assessment for the definition of cardiometabolic risk. J Endocrinol Invest 36:537-543

18. Virtue S, Vidal-Puig A (2008) It's not how fat you are, it's what you do with it that counts. PLoS Biol 23:e237

19. Steppan CM, Bailey ST, Bhat S, Brown EJ, Banerjee RR, Wright $\mathrm{CM}$ et al (2001) The hormone resistin links obesity to diabetes. Nature 409:307-312

20. Valassi E, Biller BM, Klibanski A, Misra M (2012) Adipokines and cardiovascular risk in Cushing's syndrome. Neuroendocrinology 95:187-206

21. Despres JP (2006) Is visceral obesity the cause of the metabolic syndrome? Ann Med 38:52-63

22. Nieman LK, Biller BM, Findling JW, Newell-Price J, Savage MO, Stewart PM et al (2008) The diagnosis of Cushing's syndrome: an endocrine society clinical practice guideline. J Clin Endocrinol Metab 93:1526-1540

23. Arnaldi G, Angeli A, Atkinson AB, Bertagna X, Cavagnini F, Chrousos GP et al (2003) Diagnosis and complications of Cushing's syndrome: a consensus statement. J Clin Endocrinol Metab 88:5593-5602

24. Colao A, De Block C, Gaztambide MS, Kumar S, Seufert J, Casanueva FF (2014) Managing hyperglycemia in patients with Cushing's disease treated with pasireotide: medical expert recommendations. Pituitary 17:180-186

25. Liu X, Men P, Wang Y, Zhai S, Liu G (2016) Impact of dipeptidyl peptidase-4 inhibitors on serum adiponectin: a meta-analysis. Lipids Health Dis 15:204

26. Röhrborn D, Brückner J, Sell H, Eckel J (2016) Reduced DPP4 activity improves insulin signaling in primary human adipocytes. Biochem Biophys Res Commun 471:348-354

27. Grigoropoulou P, Eleftheriadou I, Zoupas C, Diamanti-Kandarakis E, Tentolouris N (2013) Incretin-based therapies for type 2 diabetes mellitus: effects on insulin resistance. Curr Diabetes Rev 9:412-417

28. El Bekay R, Coín-Aragüez L, Fernández-García D, Oliva-Olivera W, Bernal-López R, Clemente-Postigo M et al (2016) Effects of glucagon-like peptide- 1 on the differentiation and metabolism of human adipocytes. Br J Pharmacol 173:1820-1834

29. Matthews D, Hosker J, Rudenski A, Naylor BA, Treacher DF, Turner RC (1985) Homeostasis model assessment: insulin resistance and b-cell function from fasting plasma glucose and insulin concentration in man. Diabetologia 28:412-419

30. DeFronzo RA, Tobin JD, Andres R (1979) Glucose clamp technique: a method for quantifying insulin secretion and resistance. Am J Physiol 237:E214-E222
31. Silverstein JM (2016) Hyperglycemia induced by pasireotide in patients with Cushing's disease or acromegaly. Pituitary 19:536-543

32. Trujillo ME, Scherer PE (2006) Adipose tissue-derived factors: impact on health and disease. Endocr Rev 27:762-778

33. Masuzaki H, Ogawa Y, Hosoda K, Miyawaki T, Hanaoka I, Hiraoka J et al (1997) Glucocorticoid regulation of leptin synthesis and secretion in humans: elevated plasma leptin levels in Cushing's syndrome. J Clin Endocrinol Metab 82:2542-2547

34. Weise M, Abad V, Considine RV, Nieman L, Rother KI (1999) Leptin secretion in Cushing's syndrome: preservation of diurnal rhythm and absent response to corticotrophin-releasing hormone. J Clin Endocrinol Metab 84:2075-2079

35. Gavrila A, Peng CK, Chan L, Mietus JE, Goldberger AL, Mantzoros CS (2003) Diurnal and ultradian dynamics of serum adiponectin in healthy men: comparison with leptin, circulating soluble leptin receptor, and cortisol patterns. J Clin Endocrinol Metab 88:2838-2843

36. Libè R, Morpugo PS, Cappiello V, Maffini A, Bondioni S, Locatelli $\mathrm{M}$ et al (2005) Ghrelin and adiponectin in patients with Cushing's disease before and after successful transsphenoidal surgery. Clin Endocrinol 62:30-36

37. Wagenmakers M, Roerink S, Gil L, Plantinga T, Smit J, NeteaMaier R et al (2015) Persistent centripetal fat distribution and metabolic abnormalities in patients in long-term remission of Cushing's syndrome. Clin Endocrinol 82:180-187

38. Barahona MJ, Sucunza N, Resmini E, Fernández-Real JM, Ricart W, Moreno-Navarrete JM et al (2009) Persistent body fat mass and inflammatory marker increases after long-term cure of Cushing's syndrome. J Clin Endocrinol Metab 94:3365-3371

39. Durovcová V, Marek J, Hána V, Matoulek M, Zikán V, Haluzíková D et al (2010) Plasma concentrations of adipocyte fatty acid binding protein in patients with Cushing's syndrome. Physiol Res 59:963-971

40. Rubenstein AH, Block MB, Starr J, Melani F, Steiner DF (1992) Proinsulin and C-peptide in blood. Diabetes 21:661-672

41. Palmer JP, Fleming GA, Greenbaum CJ, Herold KC, Jansa LD, Kolb H et al (2004) C-peptide is the appropriate outcome measure for type 1 diabetes clinical trials to preserve beta-cell function: report of an ADA workshop, 21-22 October 2001. Diabetes $53: 250-264$

42. Hendriksen C, Faber OK, Drejer J, Binder C (1997) Prevalence of residual B-cell function in insulin-treated diabetics evaluated by the plasma C-peptide response to intravenous glucagon. Diabetologia 13:615-619

43. Ida S, Murata K, Kaneko R (2017) Effects of metformin treatment on blood leptin and ghrelin levels in patients with type 2 diabetes mellitus. J Diabetes 9:526-535

44. Ou HY, Cheng JT, Yu EH, Wu TJ (2006) Metformin increases insulin sensitivity and plasma beta-endorphin in human subjects. Horm Metab Res 38:106-111 